\title{
CD26 immuno-expression and periodontal disease progression
}

\author{
P. M. L. Manna, J. E. Costa, and R. S. Gomez \\ Department of Oral Surgery and Pathology, Universidade Federal de Minas Gerais, Belo Horizonte, Brazil
}

\begin{abstract}
Immunological mechanisms participate in the pathogenesis of human chronic inflammatory periodontal disease (CIPD). Human $\mathrm{CD} 4{ }^{+}$lymphocytes express functionally heterogeneous profiles of cytokine production. CD26 is an integral membrane glycoprotein, that is, a marker of Th1-like cytokine development. The purpose of the present study was to compare the immuno-expression of CD26 receptor in periodontal sites with and without clinical attachment loss (CAL). Five patients with rapidly progressing periodontitis and one with juvenile periodontitis were investigated. Each patient presented at least one site with and without CAL. Ten sites with CAL and nine without any CAL were biopsied, followed by the immunohistochemical identification of the CD26 receptor using the MIB-DS2/7 antibody. The results demonstrated that the percentage of positive cells for this antigen in the periodontal sites with CAL was not significantly different from those without attachment loss. Therefore, Th1 cell impairment may not be directly involved with periodontal attachment loss.
\end{abstract}

\section{INTRODUCTION}

Immunological mechanisms have been implicated in the pathogenesis of human chronic inflammatory periodontal disease (CPID) for over 30 years. Defects in polymorphonuclear leukocytes [1], depressed cellular immune response $[2,3]$, polyclonal $\beta$-cell activation [4], and imbalance in the cytokine network [5-10] are some of the alterations reported. However, few studies have compared immunological features of active versus nonactive periodontal lesions [11].

Human $\mathrm{CD}^{+}$lymphocytes express functionally heterogeneous profiles of cytokine production [12-14]. Th1 $\mathrm{CD}^{+}$produce interleukin-2 (IL-2) and interferon- $\gamma$ (IFN$\gamma$ ), whereas Th2 cells produce mainly interleukins-4 (IL-4) and 5 (IL-5). The same pattern of cytokine profile has also been described in $\mathrm{CD}^{+}$lymphocytes. The presence of IL4 or IL-12 contributes to these highly polarized phenotypes [13-16]. Some signaling molecules, like Stat4 and Stat6, appear essential for Th1 and Th2 development, respectively. The Th1 subset induces cell-mediated immune responses, while the Th2 subset is associated with humoral-type responses.

The study of Th1 and Th2 subsets in inflammatory diseases is hampered by the lack of reliable surface markers for these cell phenotypes. Additionally, human T-cells clones form a continuous spectrum in which Th1 and Th2 cells may be only two of the possible extreme phenotypes [17]. CD30 was reported to be a marker of the Th2 profile [18], but this receptor is not strictly limited to Th2 cells [19].

CD26 is an integral type II membrane glycoprotein of $110 \mathrm{kDa}$ with a dipeptidyl peptidase IV activity [20,21]. This receptor is expressed in 10\%-60\% of peripheral blood T cells, and T-cell activation is accompanied by its enhanced expression [20-22]. CD26 immunostaining correlates with the pro- duction of IFN- $\gamma$ in granulomatous diseases [23] and additional studies implicated the CD26 receptor as a marker of Th1-like cytokines development $[17,24]$.

To examine the cellular immune response and $\mathrm{Th} 1$ subsets in human chronic inflammatory periodontal disease pathogenesis, in the present study we investigated the immunoexpression of CD26 receptor in periodontal sites with and without clinical attachment loss (CAL).

\section{MATERIALS AND METHODS}

\section{Subjects}

Six patients with early onset periodontitis (five affected with rapidly progressing periodontitis and one with juvenile periodontitis) were included in this study. They were initially treated with oral hygiene instructions, scaling and root planning, as well as plaque index assessment. After six weeks, monthly evaluations were done over a nine-month period. The evaluations consisted of probing depth, clinical attachment loss and bleeding on probing measures, using an electronic controlled-force probe (Florida Probe, Florida Probe Corporation, Gainesville, and Florida).

Small gingival biopsies were done according to the following criteria: $(\mathrm{a}) \geq 1 \mathrm{~mm}$ of CAL since the baseline therapy and $\geq 5 \mathrm{~mm}$ of pocket depth; (b) no CAL after the baseline measurement but associated with teeth designated for extraction. The biopsies were performed by incision with approximately $1.5 \mathrm{~mm}$ thickness extending from the sulcus outward through the oral epithelium and apical to the depth of the periodontal sulcus. Each patient presented at least one site with and without CAL. Ten sites with CAL and nine without CAL were biopsied. Biopsies from both groups (with and 
without CAL) were matched as closest as possible to the probing depth and clinical attachment level at the initial examination, and supragingival plaque. No patient had a history of disease or medications which might affect the microbial flora, immune system or inflammatory response. Informed consent was received from each subject and the research project was approved by the University's Ethics Committee.

\section{Immunohistochemistry}

Although many antibodies specific for CD26 receptor are available, not all of them have been found useful in identifying a Th1-like immune reaction in human tissues. Different antibodies against CD26 receptor were tested for discrimination between Th1-like and Th2-like reactions in leprosy [24]. According to these authors, although all seven antibodies used were specific for this antigen, only the MIB-DS2/7 and 2A6 were capable to identify a Th1-like immune reaction in human disease. Therefore, in the present study we used the clone MIB-DS2/7, kindly provided by Dr. Ulrike Seitzer, to identify the CD26 receptor.

Frozen sections obtained by cryostat (Microm-HM 500 $\mathrm{OM}$ ) were subjected to the biotin-streptavidin amplified system for CD26 immunostaining. Briefly, the sections were fixed in cold acetone for $10 \mathrm{~min}$ and immersed in $3 \%$ methanol-hydrogen peroxide solution for $10 \mathrm{~min}$, to block endogenous peroxidase activity. After washing in $20 \mathrm{mM}$ tris$\mathrm{HCl}$ buffer containing $0.19 \mathrm{M} \mathrm{NaCl}$ ( $\mathrm{pH} 7.4$ ), the sections were incubated with anti-CD26 (prediluted) in tris-HCl buffer for 18 hours at $4^{\circ} \mathrm{C}$. Thereafter, the sections were washed once again in tris- $\mathrm{HCl}$ buffer $(\mathrm{pH} \mathrm{7.4)}$ and incubated at room temperature with biotinylated rabbit anti-mouse immunoglobulin (DAKO) diluted 1:400 in tris- $\mathrm{HCl}$ for $30 \mathrm{~min}$; washed with tris- $\mathrm{HCl}$ twice for $10 \mathrm{~min}$; incubated for another $30 \mathrm{~min}$ with horseradish peroxidase-conjugated streptavidin (DAKO) prepared according to the manufacturer's directions; washed with tris- $\mathrm{HCl}$; incubated for three minutes with $0.01 \%$ diaminobenzidine tetrahydrochloride (DAB) and $0.3 \% \mathrm{H}_{2} \mathrm{O}_{2}$ in tris- $\mathrm{HCl}$ buffer ( $\mathrm{pH} 7.4$ ); rinsed in distilled water for $10 \mathrm{~min}$ and finally counterstained with Mayer's hematoxylin. To avoid false positive results, a series of tissue sections were stained with omission of the primary antibody.

\section{Cell quantification and statistical analysis}

The immunostaining of CD26 was quantitatively analyzed at six high-power microscopic fields at the epithelium/connective tissue interface $(400 \mathrm{x})$ through a square micrometer. The definitions of the first microscopic field were established by adjusting the square micrometer at the apical interface of the periodontal pocket epithelium/connective tissue. The results are expressed as the percentage of positive cells.

\section{Statistical analysis}

Since percentage values do not demonstrate a normal distribution, a nonparametric analysis Wilcoxon signed rank test was used to compare the means of the sites with and without
CAL. The error in cell counts was determined by six double counts in different moments and was below $2.2 \%$ of the cell-specific counts.

\section{RESULTS}

Some immunostaining was observed in the connective tissue. The cells immunostained by the antibody MIB-DS2/7 showed a lymphoid morphology. The percentage of CD26 ${ }^{+}$ cells in the periodontal sites with CAL (mean: 10.3, median: 24.6, minimal: 1.2, maximal: 47.9) was not significantly different from those without it (mean: 6.9, median: 11.0, minimal: 2.1, maximal: 15.1).

\section{DISCUSSION}

Cytokines are particularly important for immune system regulation and T-lymphocytes have a central role in it. Th1 and Th2 cells induce cell-mediated and humoral-type immune responses, respectively $[12,24]$. Th1 and Th2 lymphocytes are a polarized spectrum of T-cell differentiation and not distinct $\mathrm{T}$-cell clones and their products regulate the differentiation and the effector functions of the reciprocal subset [13-16]. The definition of Th1 or Th2 cells is based primarily on the type of cytokines produced. Recently, the CD26 receptor was suggested as a marker of Th1-like cytokine development $[17,24]$. In the present study, we used the antibody MIB-DS2/7 for CD26 immunostaining. This antibody is useful to identify the Th1 cells in inflammatory diseases [24].

The regulation of the immune system in human chronic inflammatory periodontal disease has been extensively studied. Seymour et al. [25] and Gemmell et al. [26] proposed that the progression of periodontal diseases is characterized by a shift from a predominantly Th1 to a Th2 cell profile. This hypothesis is supported by some studies [2, 7, 11, 2731 ] but has not been confirmed by others [32,33]. Ellis et al. [10] suggested that progressively lower gingival concentrations of IL- 12 and higher IL- 6 concentrations associated with increasing sulcular depth not only indicates a shift from a Th1 to a Th2 immunologic phenotype, but also suggests a regulatory role for IL-12 in that shift. Considering that different methodologies were used in these studies, a definitive conclusion about Th1 and Th2 cells and periodontal disease activity cannot be achieved.

In the current study, we have not observed any differences in CD26 immunostaining between the periodontal sites with and without CAL. These data suggest that Th1 cell impairment is not directly involved with periodontal attachment loss. However, we used a longitudinal assay to discriminate active versus nonactive periodontal sites. The samples in the active sites were collected after periodontal attachment loss. Therefore, the possibility that we analyzed a postactive event cannot be completely ruled-out. Furthermore, the extent of active or inactive periods in periodontal disease is not known [34]. If periodontal pockets have prolonged periods of inactivity plus brief episodes of localized exacerbation, the protocol used would not discriminate the lesions susceptible to 
periodontal breakdown from those which are quiescent. This could be due to the poor resolution of the available clinical measurements [35].

In conclusion, our study shows that periodontal sites with and without attachment loss do not have different numbers of Th1 cells and further studies are necessary to clarify the importance of Th1 cells in the biological activity of periodontal disease.

\section{ACKNOWLEDGMENTS}

This study was supported by grants from $\mathrm{CNPq}$, FAPEMIG, PRONEX, and PADCT, Brazil. RS Gomez is research fellow of CNPq. We thank Dr. L. De Marco for reading this manuscript.

\section{REFERENCES}

[1] Gomez RS, Costa JE, Lorentz TM, Garrocho AA, Nogueira-Machado JA. Chemiluminescence generation and MTT dye reduction by polymorphonuclear leukocytes from periodontal disease patients. J Periodont Res. 1994;29:109-112.

[2] Kinane DF, Johnston FA, Evans CW. Depressed helperto-suppressor T-cell ratios in early-onset forms of periodontal disease. J Periodont Res. 1989;24:161-164.

[3] Sigusch B, Klinger G, Glockmann E, Simon HU. Earlyonset and adult periodontitis associated with abnormal cytokine production by activated T lymphocytes. J Periodontol. 1998;10:1098-1104.

[4] Tew J, Engel D. Polyclonal B-cell activation in periodontitis. J Periodont Res. 1989;24:225-241.

[5] McFarlane CG, Meikle MC. Interleukin-2, interleukin-2 receptor and interleukin-4 levels are elevated in the sera of patients with periodontal disease. J Periodont Res. 1991;26:402-408.

[6] Fujihashi K, Kono Y, Beagley KW, Yamamoto M, McGhee JR, Mestecky J, Kiyono H. Cytokines and periodontal disease: Immunopathological role of interleukins for B cell responses in chronic inflamed gingival tissues. J Periodontol. 1993;64:400-406.

[7] Manhart SS, Reinhardt RA, Payne JB, Seymour GJ, Gemmell E, Dyer JK, Petro TM. Gingival cell IL-2 and IL-4 in early onset periodontitis. J Periodontol. 1994;65:807813.

[8] Page CR, Offenbacher S, Schroeder HE, Seymour GJ, Kornman KS. Advances in the pathogenesis of periodontitis: summary of developments, clinical implications and future directions. Periodontology. 2000;14:216-248.

[9] Yamamoto M, Fujihashi K, Hiroi T, McGhee JR, Van Dyke TE, Kiyono H. Molecular and cellular mechanisms for periodontal diseases: role of Th1 and Th2 type cytokines in induction of mucosal inflammation. J Periodont Res. 1997;32:115-119.

[10] Ellis SD, Tucci MA, Serio FG, Johnson RB. Factors for progression of periodontal diseases. J Oral Pathol Med. 1998;27:101-105.

[11] Reinhardt RA, Masada MP, Kaldahl WB, et al. Gingival fluid IL-1 and IL-6 levels in refractory periodontitis. $J$ Clin Periodontol. 1993;20:225-231.

[12] Mosmann TR, Coffman RL. TH1 and TH2 cells: different patterns of lymphokine secretion lead to different functional properties. Ann Rev Immunol. 1989;7:145173.

[13] Mosmann TR, Sad S. The expanding universe of Tcell subsets: Th1, Th2 and more. Immunol Today. 1996;17:138-146.

[14] Kelso A. Cytokines: principles and prospects. Immunol Cell Biol. 1998;76:300-317.

[15] Murphy KM. T lymphocyte differentiation in the periphery. Curr Opin Immunol. 1998;10:226-232.

[16] Paludan SR. Interleukin-4 and interferon- $\gamma$ : the quintessence of a mutual antagonistic relationship. Scand J Immunol. 1998;48:459-468.

[17] Willheim M, Ebner C, Baier K, et al. Cell surface characterization of $\mathrm{T}$ lymphocytes and allergen-specific $\mathrm{T}$ cell clones: Correlation of CD26 expression with Th1 subsets. J Allergy Clin Immunol. 1997;100:348-355.

[18] Del Prete GF, Maggi E, Pizzolo G, Romagnani S. CD30, Th2 cytokines and HIV infection: A complex and fascinating link. Immunol Today. 1995;16:76-80.

[19] Agrawal B, Reddish M, Longenecker BMJ. CD30 expression on human CD8+ T cells isolated from peripheral blood lymphocytes of normal donors. J Immunol. 1996;157:3229-3234.

[20] Bonin AV, Hühn J, Fleischer B. Dipeptidyl-peptidase IV/CD26 on T cells: analysis of an alternative T-cell activation pathway. Immunological Reviews. 1998;161:4353.

[21] Morimoto C, Schlossman S. The structure and function of CD26 in the T-cell immune response. Immunol Rev. 1998;161:55-70.

[22] Fleischer B. CD26: a surface protease involved in T cell activation. Immunol Today. 1994;15:180-184.

[23] Sheel-Toellner D, Richter E, Toellner KM, et al. CD26 expression in leprosy and other granulomatous diseases correlates with the production of interferon-gamma. Lab Invest. 1995;73:685-690.

[24] Seitzer U, Scheel-Toellner D, Mattern T, Haas H, Flad $\mathrm{HD}$, Gerdes H. Staining pattern of seven monoclonal anti-CD26 antibodies in leprosy: implications for the used of CD26 as a surrogate marker of a human Th1like reaction. Virchows Arch. 1998;432:343-347.

[25] Seymour GJ, Gemmell E, Reinhardt RA, Eastcott J, Taubman MA. Immunopathogenesis of chronic inflammatory periodontal disease: cellular and molecular mechanisms. J Periodont Res. 1993;28:478-486.

[26] Gemmell E, Marshall RI, Seymour GJ. Cytokines and prostaglandins in immune homeostasis and tissue destruction in periodontal disease. Periodontol 2000. 1997;14:112-143.

[27] Yamazaki K, Nakajima T, Hara K. Immunohistological analysis of $\mathrm{T}$ cell functional subsets in chronic inflammatory periodontal disease. Clin Exp Immunol. 1995;79:384-391. 
[28] Aoyagy T, Sugawara-Aoyagi M, Yamazaki K, Hara K. Interleukin 4 (IL-4) and IL-6-producing memory Tcells in peripheral blood and gingival tissues in periodontitis patients with high serum antibody titers to Porphyromonas gingivalis. Oral Microbiol Immunol. 1995; 10:304-310.

[29] Gomez RS, Souza PEA, Costa JE, Araújo NS. CD30+ lymphocytes in chronic gingivitis from HIV-positive patients: A pilot study. J Periodontol. 1997;68:881-883.

[30] Gemmell E. Seymour GJ. Cytokine profiles of cells extracted from humans with periodontal diseases. J Dent Res. 1998;77:16-26.

[31] Iwasaki Y, Hara Y, Koji T, Shibata Y, Nakane PK, Kato I. Differential expression of IFN-gamma, IL4, IL-10, and IL-1 beta mRNA in decalcified tissue sections of mouse lipopolyssaccharide-induced periodontitis mandibles assessed by in situ hibridization. Histochem Cell Biol. 1998;109:339-347.
[32] Ebersole JL, Taubman MA. The protective nature of host responses in periodontal diseases. Periodontol 2000. 1994;5:112-141.

[33] Prabhu A, Michalowicz BS, Mathur A. Detection of local and systemic cytokines in adult periodontitis. J Periodontol. 1996;67:515-522.

[34] Lindhe J. Clinical Periodontology and Implant Dentistry. Copenhagen: Munksgaard. 1998.

[35] Jeffcoat MK, Reddy MS. Progression of probing attachment loss in adult periodontitis. J Periodontol. 1991;62:185-189.

* Corresponding author. Current address: Departamento de Clínica, Patologia e Cirurgia Faculdade de Odontologia Rua Conde de Linhares, 141 Belo Horizonte, 30380-030, Brasil

E-mail: rsgomez@net.em.com.br 


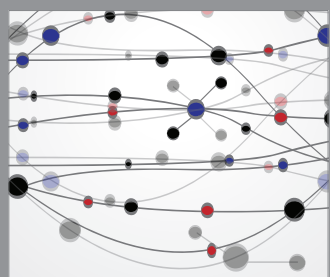

The Scientific World Journal
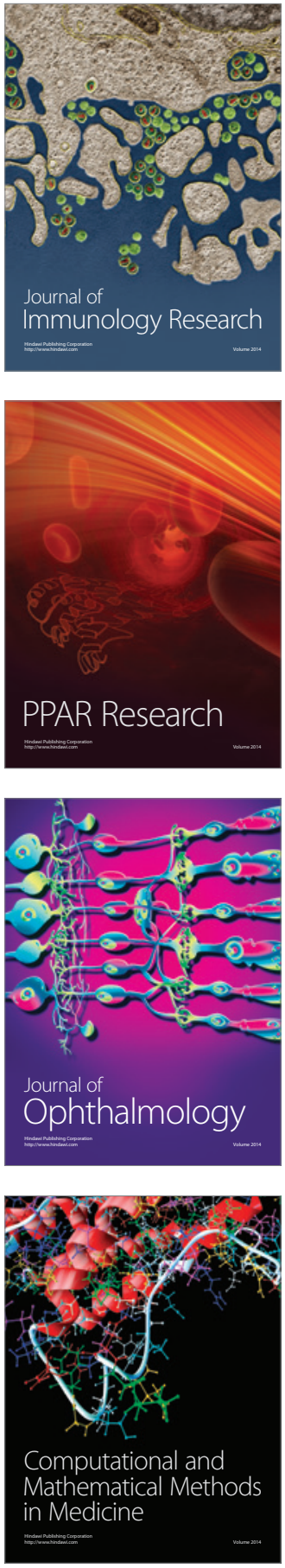

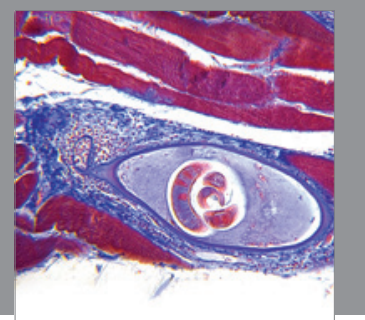

Gastroenterology

Research and Practice
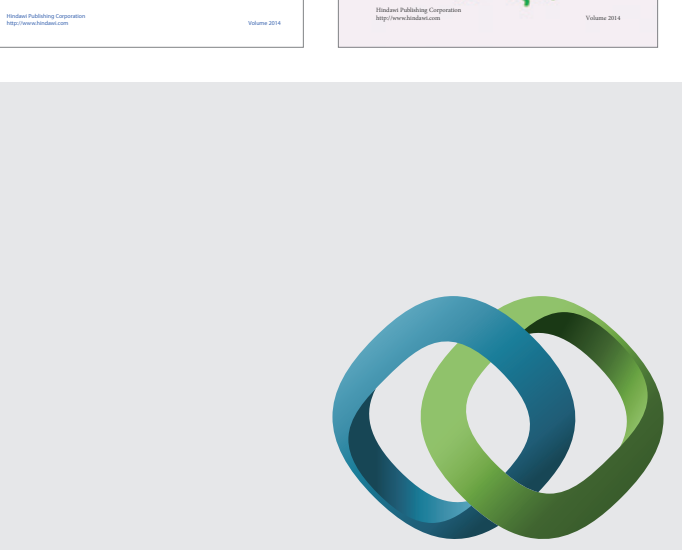

\section{Hindawi}

Submit your manuscripts at

http://www.hindawi.com
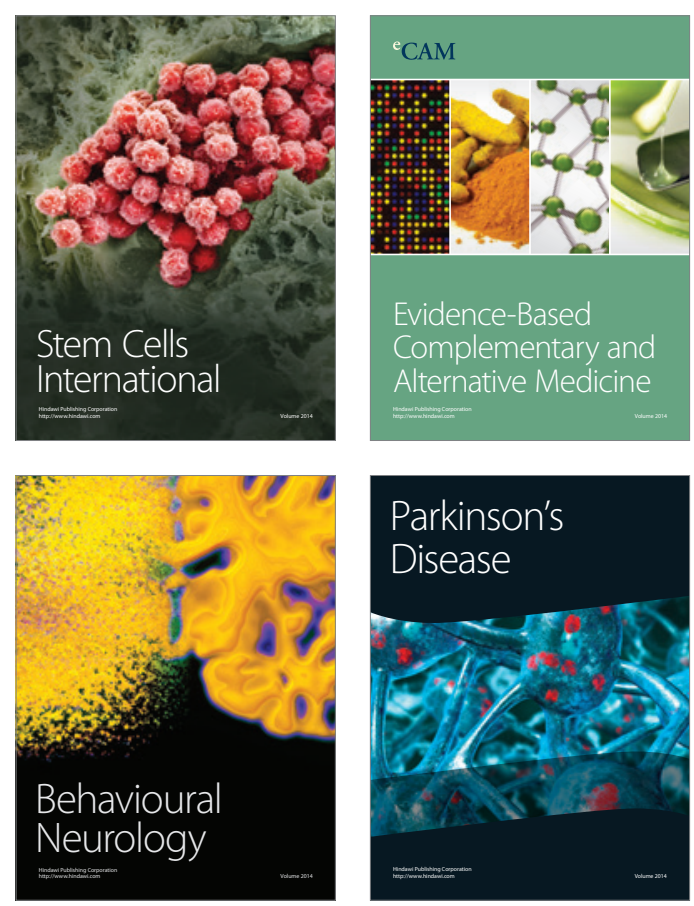

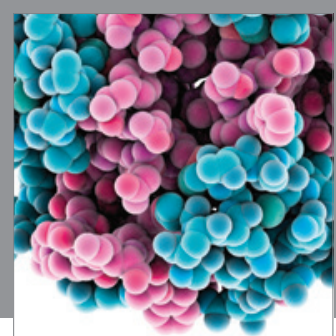

Journal of
Diabetes Research

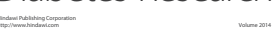

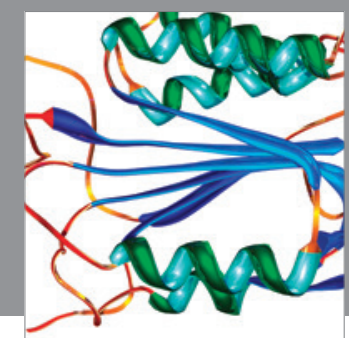

Disease Markers
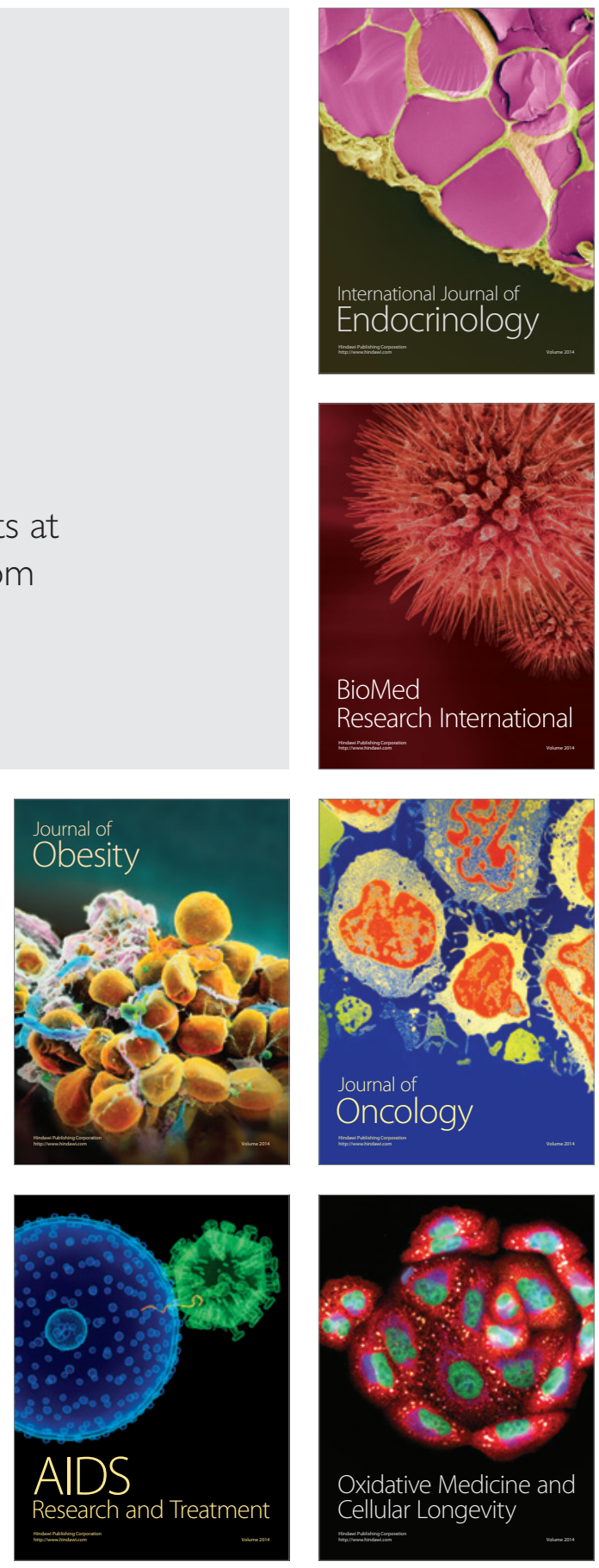